\title{
Urban Construction Blasting in Canada - Complaints and Associated Municipal Bylaws
}

\author{
Jeff Loeb $^{1,2}$, Dwayne D. Tannant ${ }^{1, *}$ \\ ${ }^{1}$ School of Engineering, University of British Columbia, Kelowna, B.C., Canada V1V 1V7 \\ ${ }^{2}$ Now with Blast Movement Technologies, Seventeen Mile Rocks, Qld, Australia \\ *Corresponding Author: dwayne.tannant@ubc.ca
}

Copyright (C) 2014 Horizon Research Publishing all rights reserved.

\begin{abstract}
Blasting in urban environments frequently results in both legitimate and frivolous complaints even though effective blasting practices and associated protective measures exist. Analysis of blasting-related complaints and the existing state of blasting regulations applicable to Canadian municipalities was conducted. Provincial blasting regulations typically do not prescribe the need for notification of planned blasts, pre-blast surveys, and blasting monitoring. In the absence of these requirements, some municipalities have developed their own blasting bylaws. Anecdotal results suggest that when a well-designed municipal blasting bylaw is present and is enforced, then complaints from the public are greatly reduced. To aid municipalities, this paper presents a generic blasting bylaw along with recommendations for a blast-notification protocol that were developed with input from blasting contractors and consultants. Key features in the bylaw require the blaster to 1) obtain a municipal blasting permit, 2) notify residents within a specified distance from the blast site of impending blasts, 3 ) carry out pre-blast surveys, and 4) use a third-party vibration-monitoring consultant.
\end{abstract}

Keywords Urban Blasting; Construction Practices; Public Complaints; Municipal Bylaws; Pre-blast Surveys; Damage Thresholds; Peak Particle Velocity

\section{Introduction}

Blasting for construction purposes in urban areas frequently receives negative media attention driven by complaints of vibration and overpressure made by people living near the blast sites. Trained blasters can use appropriate blasting techniques to minimize adverse effects caused by blasting and most blasts performed in urban areas create no problems. However, a general absence of prescriptive regulations allows some blasters to conduct blasting activities without the need to consider effects on nearby people and homes.

This paper documents the complaints related to vibration and overpressure resulting from urban blasting in Canada, with a focus on the provinces of British Columbia (B.C.) and Ontario. The blasting regulations within Canada are compared and evaluated. A comparative analysis of incidents and complaints, complemented with different approaches used to regulate blasting in various municipalities in B.C. is presented.

Based on interviews with provincial and municipal regulators, blasting contractors, and blasting consultants, a new generic municipal bylaw to regulate urban blasting practices and to minimize complaints from nearby residents is presented. The development of urban blasting bylaw is intended to achieve the following objectives:

- create better relationships between blasting contractors and affected residents,

- reduce complaints coming from people living and working near urban blasts,

- reduce frivolous damage claims against blasting contractors made by affected homeowners, and

- minimize liability exposure for municipalities.

\section{Background}

\subsection{Vibration}

Ground vibrations are an unavoidable environmental effect of urban blasting. Neighboring structures, including residential homes can sustain damage during blasting due to [1]:

- permanent ground deformation due to heave or gas pressures,

- vibratory settlement of a building foundation, and

- direct vibratory cracking in a building due to ground vibrations.

Whether damage to nearby home occurs because of blasting depends on the magnitude of the induced vibrations and the quality and type of the home construction. Ground vibrations are typically measured in terms of peak particle velocity $(\mathrm{mm} / \mathrm{s})$ and frequency $(\mathrm{Hz})$. Empirical relationships exist between ground vibrations, the distance from a blast to 
the point of interest, and the weight of explosives detonated [2]. The blaster may monitor a blast using a seismometer to measure the ground vibrations, which can be plotted on a damage threshold plot. Various damage thresholds have been established around the world. For example, Siskind et al. [3] present a threshold plot commonly used in North America to define vibration levels that may trigger onset of cosmetic damage in houses. A similar plot of peak particle velocity versus frequency is presented by Dowding [1], which shows slightly different thresholds. The higher threshold recommended by the United States Office of Surface Mining is for onset of damage, whereas the lower threshold in the German DIN 4150 Standard [4] is for annoyance limits.

Koeman v. Pacific Blasting \& Demolition Ltd. is an example of compensation being awarded to a homeowner arising from damage attributed to vibrations generated by nearby blasting. In $R$. v. Chenard, a blaster was convicted of damaging a nearby house. Conversely, Greco v. Zulich Construction Corp. is a case in which a frivolous claim of damage associated with blasting vibrations was dismissed by the court.

\subsection{Overpressure}

Overpressure, or air blast, is the term used to describe the pressure waves in the air exerted from an explosion [1,5]. The amplitude of the air pressure is the parameter of importance. Higher-frequency waves produce the familiar sound that accompanies blasting. However, it is the lower-frequency, non-audible portion that excites structures and may cause a secondary audible rattle within a building.

Two hazards that air blasts pose are direct human annoyance from the noise and air pressure causing damage to neighboring structures such as breaking windows [1]. A special microphone connected to a seismometer can measure the overpressure. The safe limit for air blast overpressure ranges from $115 \mathrm{~dB}$ to $133 \mathrm{~dB}$ based on guidelines from Australia, USA, United Kingdom, and Canada [6]. It is recognized that noise levels between 120 and $133 \mathrm{~dB}$ will likely not cause structural damage; they will however generate numerous complaints from affected residents.

\subsection{Flyrock}

Flyrock is rock that is thrown by the blast beyond the boundaries of the blast site. There are numerous examples of flyrock damaging nearby buildings during urban blasting in Canada. For example, in Director of Occupational Health and Safety v. Government of Yukon, William R. Cratty and P. S. Sidhu Trucking Ltd. the court elected to apply the Yukon Occupational Health and Safety Act to include the affected public in addition to workers at the blast site when convicting the blaster and the construction company as a result of flyrock hitting nearby homes.

In HMQ (MOE) v. Castonguay Blasting Ltd. and Ontario (Environment) v. Castonguay Blasting Ltd., a blasting contractor was convicted of discharging a contaminant into the natural environment out of the normal course of events that caused an adverse effect, and failing to notify the Ministry of the Environment. The contaminant in this case was flyrock that went through the roof of a house and the Ontario Environmental Protection Act was the governing statute. The blasting company appealed their conviction and lost arguing that flyrock should not be considered as "discharging a contaminant that caused an adverse effect".

\subsection{Mitigation Techniques}

Blasting knowledge and technology has improved significantly in recent decades. Stark [7] argues that improvements in blasting technologies over the past 40 years should allow urban blasting to no longer be considered abnormally dangerous and thus should fall under a negligence, not strict tort liability, legal framework. There is now extensive literature that provides best-practice guidelines to reduce the disturbance and damage caused by blasting vibrations and overpressures [1,2,8-11].

Trained blasters should be competent in mitigating the effects of vibration and overpressure. Pre-blast surveys of nearby structures and the use of a seismometer to measure vibrations and overpressure resulting from the blast are considered best practices and are recommended to verify the effectiveness of blast designs.

\section{Current Urban Blasting Regulations}

Various federal and provincial regulations govern aspects of explosives manufacturing, transportation, and storage. The Canadian federal government has guidelines and regulations such as the Explosive Act, Explosives Regulations, and Transportation of Dangerous Goods Regulations that are directly related to the safety and security of manufacturing explosives, their storage, import, and transportation into and within the country. However, these regulations do not apply to the act of blasting to excavate rock.

The provincial regulations governing blasting for construction purposes outside of a mine site typically fall under Occupational Health and Safety regulations in various provinces. These regulations tend to focus on safety of employees on a construction site and may include explicit reference to the need to control flyrock.

In British Columbia, WorkSafeBC states that "the blaster must take precautions for the protection of persons and property, including proper loading and stemming of holes, and where necessary, the use of cover for the blast or other effective means of controlling the blast or resultant flying material" (British Columbia Occupational Health and Safety Regulation, Part 21). The Ministry of Mines has similar laws and regulations to ensure safety of persons and property near mines and quarries (British Columbia Mines Act). However, the British Columbia Occupational Health and Safety 
Regulation is not very prescriptive in defining what actions should be taken to protect persons and property exposed to urban blasts. Thus, the onus is on the blaster to select suitable precautions and protective measures.

In Ontario, provisions protecting the safety of blasters and other personnel on the blasting site are outlined in Part VI of Regulation 854 - Mines and Mining Plants, as well as Regulation 213 - Construction Projects under the Ontario Occupational Health and Safety Act.

At the municipal level, every bylaw with some component related to blasting that was publicly available on municipal websites in B.C. was examined. Most municipalities have no regulations at all. A summary of municipal blasting regulations in B.C. is provided in Table 1. Only 24 of the 157 municipalities in B.C. have a bylaw that mentions blasting. Existing bylaws range from requiring only a permit without any regulations to prescriptive regulations such as those found in West Vancouver and Sechelt.

A summary of the various regulating bodies, their jurisdiction, and extent of regulations is provided in Figure 1. The percentages shown on this figure correspond to the number of people (not the number of municipalities) living in B.C. municipalities with a similar degree of regulatory control on urban blasting. Only $2 \%$ of the B.C. population lives within a jurisdiction that explicitly requires blasters to monitor their blasts with a seismometer. When a complaint is made, the person will often call the city hall, of which 136 out of 157 municipalities may be unaware that blasting is occurring due to a lack of a municipal blast permitting process. Dispute resolution is further complicated when monitoring of vibrations and overpressures is not performed.

Table 1. Municipalities in British Columbia with blasting-related bylaws

\begin{tabular}{|c|c|c|c|c|c|c|c|}
\hline Municipality & Bylaw No. & $\begin{array}{c}\text { Blasting } \\
\text { Permit } \\
\end{array}$ & $\begin{array}{c}\text { Blast } \\
\text { Monitoring }\end{array}$ & $\begin{array}{c}\text { Notification of } \\
\text { Blasting }\end{array}$ & $\begin{array}{c}\text { Pre-Blast } \\
\text { Surveys }\end{array}$ & $\begin{array}{l}\text { Consultant } \\
\text { (Mandatory) }\end{array}$ & $\begin{array}{c}\text { Consultant (Upon } \\
\text { Request) }\end{array}$ \\
\hline Abbotsford & $1941-2010$ & yes & & yes & & & yes \\
\hline Burnaby & 138 & yes & & yes & & & \\
\hline Campbell River & 1874 & yes & & yes & & & \\
\hline Colwood & 272 & yes & yes & yes & yes & & yes \\
\hline Highlands & 67 & yes & yes & yes & & & yes \\
\hline Invermere & 1346 & yes & & yes & & & \\
\hline Metchosin & 230 & yes & yes & yes & & & \\
\hline Nanaimo & 4750 & & & & & & \\
\hline North Cowichan & 3255 & yes & yes & yes & yes & & \\
\hline North Vancouver & 2643 & yes & & yes & & & \\
\hline Parksville & 1432 & & & & & & \\
\hline Peachland & 701 & yes & & & & & \\
\hline Port Coquitlam & 2961 & yes & & yes & & & \\
\hline Prince Rupert & 2524 & yes & & yes & & & \\
\hline Rossland & 2460 & yes & & & & & \\
\hline Saanich & 6821 & yes & & & & & \\
\hline Sechelt & 458 & yes & yes & yes & yes & yes & \\
\hline Sooke & 72 & yes & & yes & & & \\
\hline Squamish & 188 & yes & & & & & \\
\hline Surrey & 3551 & yes & & & & & \\
\hline Terrace & 1051 & & & & & & \\
\hline Victoria & 06-008 & yes & & yes & & & \\
\hline West Vancouver & 4024 & yes & yes & yes & yes & yes & \\
\hline West Kelowna & 71 & yes & & yes & & & \\
\hline
\end{tabular}



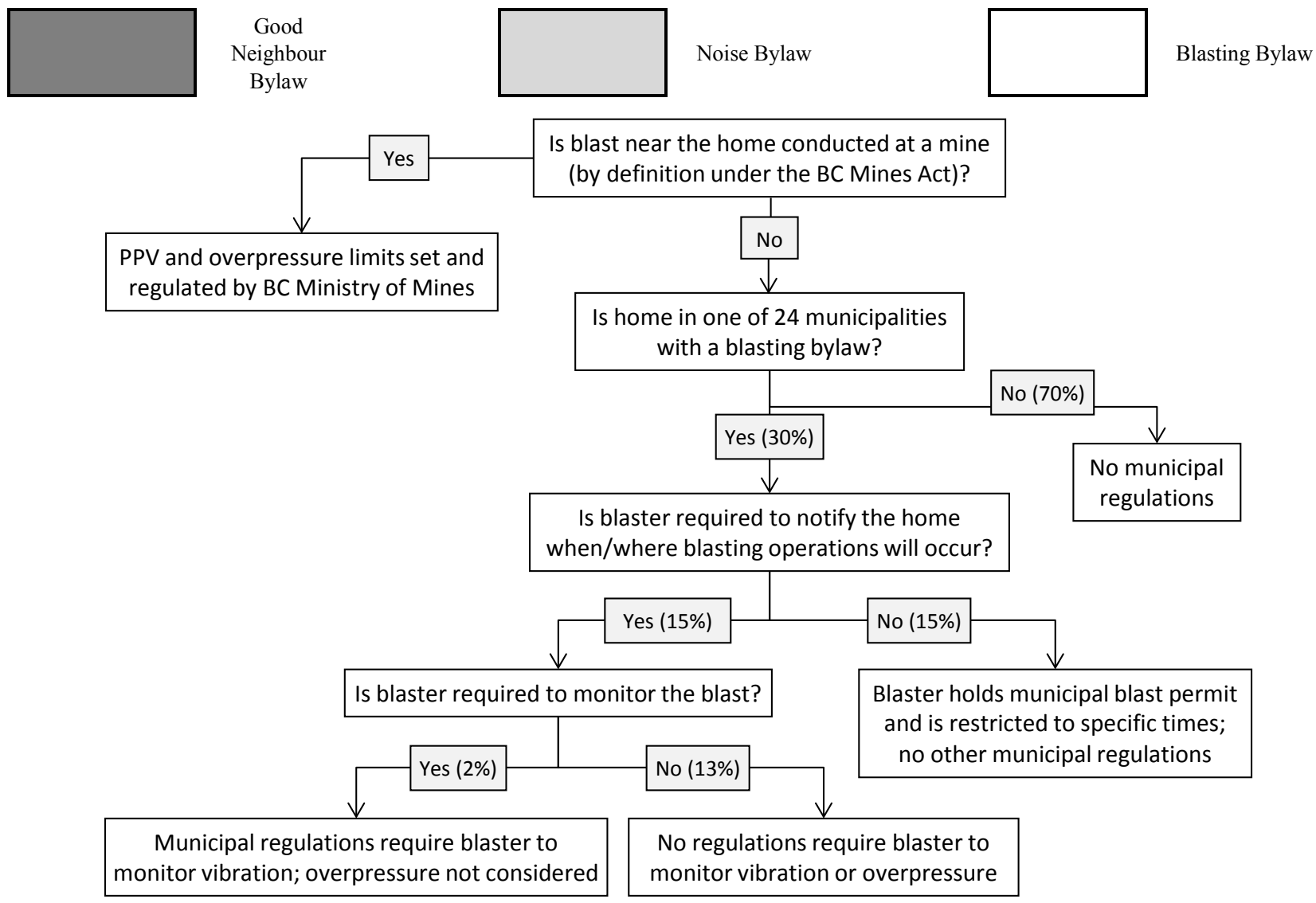

Figure 1. Regulatory control for urban blasting in British Columbia; the B.C. population percentage living in municipalities with similar regulatory control is shown in brackets

\section{Difficulties Regulating Blasting at the Municipal Level}

Municipalities prefer that blasting be regulated provincially or federally. However, the presence of municipal blasting bylaws is evidence that some municipalities do not believe the current provincial and federal regulations are sufficient. However, it is difficult for a municipality to develop and adopt a bylaw that attempts to regulate urban blasting operations. Municipalities generally have little or no blasting expertise within municipal staff, including the engineering department, and lack funding for blast monitoring and compliance. Municipal employees often have a poor understanding of which regulating bodies have control over blasting. In addition, municipalities tend to want to protect themselves by avoiding of the assumption of liability related to blasting activities.

\subsection{Lack of Understanding}

In Kelowna, B.C., residents are concerned that blasting may damage their property. Discussions among the city's engineering staff noted that "with several different ministries responsible for regulating various aspects of blasting, residents and politicians alike often don't know who to turn to if they have concerns" [12].
Sudbury, Ontario has experienced similar difficulties with an absence of control over urban blasting. City officials take complaint calls and directing them to the Ministry of the Environment, who they assume have jurisdiction, but who then revert the complaints back to the municipal authorities [13].

\subsection{Lack of Expertise and Funding}

Municipal governments do not have blasting experts readily available without expensive consulting costs. In response, municipalities attempt to hand the issue back to the larger budgeted provincial governments. Meeting minutes from an internal City of Sudbury discussion [14] state:

"...from a legal liability perspective, taking on the regulation of blasting for commercial/residential activity in the City may be more than the corporation is prepared to take on at this time. The city has neither the staff nor expertise (e.g. rock engineers) on hand to deal with this. It was felt that the Ministry of the Environment is in a better financial position to expand its role to include this activity".

In British Columbia, a city councilor suggested a more efficient solution [15]:

"a more productive course of action would be for cities to band together and lobby the provincial government for changes. Rather than us tackling it one city at a time this 
should be something that's brought back to the provincial government which does have legislative authority [to regulate blasting]".

Furthermore, if a bylaw is adopted by a municipality it can be difficult from an administrative standpoint to enforce the bylaw. The City of Ottawa implemented a municipal explosives bylaw [16] in 1982. However, it was repealed in 2003 in response to changes made to the Ontario Municipal Act. The revised Municipal Act does not provide municipalities with legislative authority to enact explosives bylaws. The City of Ottawa was advised to not seek provincial approval for special legislation to enact an explosives by-law [16]. Some municipalities regulate the use of explosives through standard specifications and other mechanisms within blasting contract documents.

\subsection{Assumption of Liability}

All municipalities currently debating the implementation of blasting bylaws are concerned about the assumption of liability. In addition, they feel uncomfortable about adopting scientific limits on unfamiliar blasting parameters such as peak particle velocity. Gorman [17] writes:

"Currently, blasting is not regulated by most municipalities nor the province, but Nanaimo city council is taking a look to see if it should step in to oversee the practice. It's approaching the issue cautiously. 'The municipality takes on the risk if a bylaw is passed,' said Toby Seward, the city's director of development".

\section{Incidents and Complaints}

General urban blasting-related complaints in Canada were gathered from newspapers reports nationwide and through meetings with municipal engineers at six British Columbia municipalities. It was found that vibration and overpressure are the root cause of nearly all complaints. Note that personal and property damage arising from flyrock results in complaints too, but these are adequately dealt with. Some examples are discussed below.

\subsection{Ontario}

At least 37 neighbors of a proposed Wal-Mart foundation excavation in Sudbury considered pursuing a class action lawsuit against a blasting contractor for their disregard for the surrounding community [18]. The most common complaints were cosmetic damage to their homes. There was no requirement for the blasting contractor to hire an independent company or perform pre-blast surveys or to monitor the blast. The blasting company monitored the blast themselves leaving a bias in the data, which were very poor and inconclusive. An independent engineer investigated the matter. However, without sufficient data, including a concise record of blast logs, location of monitoring equipment, and detailed peak particle velocity recordings, it was difficult to identify the source of the damage. Resolution of the damage claims was a very slow process, which further increased concerns from the affected homeowners.

In a letter sent from the Minister of the Environment to the Mayor of Sudbury, it was made very clear that construction blasting related issues fell under the jurisdiction of the City of Sudbury. The Minister clarifies [14]:

"It remains outside the Ministry of the Environment's mandate to regulate commercial/residential development activities that are permitted through the municipal planning process or by the issuing of a building permit. The current blasting policies and guidelines that the Province is authorized to approve deal primarily with activities such as mines, pits and quarries. The Ministry of the Environment has no approval requirements for most municipal activities related to residential and commercial development".

In a discussion with a blasting consultant in Ontario (anonymous) he expressed his concern with projects like this where a consultant is not retained. He stated that the difficulty with resolving these issues is that, in his opinion, a majority of the damage claims were not the result of blasting. The damage claimed to be a result of blasting typically was pre-existing, however due to the absence of regulations requiring blast monitoring and/or pre-blast surveys, proving this in court becomes much more difficult. A panel of stakeholders is now developing a blasting bylaw for the City of Sudbury.

\subsection{British Columbia}

Another common, but reasonable complaint made by nearby residents of a blast site is poor warning or notification of blasting prior to the commencement of blasting. In response to complaints about the size of blasts, vibrations, lack of warnings, and potential damage to homes, the District of West Kelowna developed a section of blasting regulations under the Good Neighbour Bylaw[19]. Section 2.9 of this bylaw states that: "the holder of a Blasting Permit may not commence or allow blasting or blasting operations until such time as the holder of the Blasting Permit has given notification to the neighborhood as required by the terms of the Blasting Permit and as required by the communications plan, as approved by the Director of Engineering or the Director of Building and Regulatory Services who issued the Blasting Permit". In December 2010, a few weeks after the implementation of this bylaw, a blast crew was criticized in a local newspaper for making a poor attempt at notifying a neighbor of a blast just moments before detonation [20]. Although the bylaw stipulates communication of blasting procedures to neighbors of a blast, it was not fully satisfying the community's needs.

\subsection{Perception Versus Reality}

The lack of regulations requiring blast monitoring is not the only issue surrounding vibration and overpressure disputes. The other contributing factor is the public's lack of 
blasting knowledge, and the absence of regulations requiring blasters to establish effective notifications with the affected public. A typical homeowner is alarmed by the noise and vibrations they experience when a nearby blast occurs. They also believe these are harmful to their home. However, the blasting-related vibrations and noise are usually much less damaging than routine effects due to temperature and humidity changes in a house. It is proposed that erroneously perceived negative effects of vibrations and overpressure, as well as frivolous damage claims, can be reduced by establishing an early open communication and education program between the blasting contractor and the nearby homeowners. To aid this objective, it is recommended that the blaster or the blast monitoring company distribute a blast notification pamphlet with background information about blasting to nearby homeowners [21].

\section{Bylaw Development}

In the absence of more prescriptive provincial regulations requiring pre-blast surveys and blast monitoring for urban blasting, it is apparent that development of a generic municipal bylaw to control complaints related to blasting would help many municipalities in B.C. and across Canada. In developing the bylaw, there was an effort to balance the practical needs of a blasting contractor whereby the application of the bylaw would not excessively impede their productivity. In addition, the intent of the bylaw is to minimize:

- frivolous claims for property damage,

- complaints of vibration and overpressure made by affected homeowners,

- time commitment by the city engineer or inspector and costs to the municipality, and

- liability exposure to the municipality.

Using the criteria listed above, the effectiveness of current bylaws was analyzed. Six municipalities from B.C. were chosen and organized into the following categories:

Heavily regulated (West Vancouver and Sechelt) $[22,23]$ - Bylaw requires blaster to monitor every blast, conduct pre-blast surveys, notify affected homeowners of blasting, and the owner must retain a blast consultant to supervise all blasting operations / ensure compliance with bylaw.

Moderately regulated (Colwood and Highlands) [24,25] - Specifications within the bylaw vary including pre-blast surveys, monitoring blasts, notification to neighbors. However, blast consultants are not used. The municipalities maintain a 'self-regulating' approach and reserve the right to request seismographs, or pre-blast surveys at any time. If the blaster cannot provide the information, their permit is revoked.

Not regulated(Nanaimo and Kelowna) - No bylaws are present.

Discussions were held with the city engineers and inspectors at these municipalities. For West Vancouver, Sechelt, Colwood, and Highlands, the bylaws were inspected and analyzed in terms of complaints, liability exposure, and time commitment. In addition, advantages and downfalls of each municipality's bylaw, as well as proposed amendments were discussed. For Nanaimo and Kelowna, municipalities without a blasting bylaw, interviews were used to tabulate desirable characteristics in a blasting bylaw.

Results of these discussions are provided in Table 2, which indicates that as a bylaw becomes more prescriptive, there is less liability exposure to the municipality. When comparing Sechelt and West Vancouver, the requirement for the consultant to be a professional engineer rather than a specialist is found to reduce complaints more for West Vancouver. When the data are normalized to time commitment per blasting permit, the time required by the West Vancouver city engineer is not significantly greater than the engineer and inspector in the Districts of Colwood and Highlands respectively. Most importantly, complaints are also reduced to less than one per year. Without taking into account the effect that these bylaws have on blasting productivity, Table 2suggests that the West Vancouver bylaw best meets the bylaw design criteria.

Another example of a prescriptive blasting bylaw in Canada is the one adopted by the city of Halifax [26], Nova Scotia in 2003 just three months after rocks, ranging in size from pebbles to $150 \mathrm{~kg}$, were launched from an urban blast site and crashed into an occupied apartment building [27]. The West Vancouver and Halifax bylaws have many similarities.

The findings from our investigations were presented to municipal and provincial regulators, blasting consultants, and blasting contractors across Canada. A draft urban blasting bylaw was created using feedback from these stakeholders and an iterative approach was used to create a generic bylaw that met consensus. The first draft of the bylaw was written using the bylaws from West Vancouver and Halifax as guidance. However, implementation of a highly prescriptive bylaw such as those from these two municipalities that demand extensive pre-blast surveys and blast monitoring could significantly increase the costs of construction and hence there was effort to include the opinions and recommendations of blasting consultants and blasting contractors in the bylaw.

The initial draft of the bylaw was presented and discussed at the 2011 Annual General Meeting of the Western Canadian Chapter of the International Society of Explosives Engineers. In attendance were stakeholders from the blasting and construction industries. Useful recommendations for improvements to the bylaw were obtained from this discussion and these were used to modify the draft bylaw [21]. The final version of the recommended generic blasting bylaw is presented in the appendix to this paper. 
Table 2. Municipal regulatory control on blasting in six B.C. municipalities

\begin{tabular}{|c|c|c|c|c|c|c|c|c|}
\hline Municipality & $\begin{array}{l}\text { Blasting } \\
\text { Permit }\end{array}$ & Notification & $\begin{array}{l}\text { Vibration } \\
\text { Limit }\end{array}$ & $\begin{array}{l}\text { Pre-Blast } \\
\text { Surveys }\end{array}$ & $\begin{array}{l}\text { P.Eng. or } \\
\text { Specialist }\end{array}$ & Risk $^{1}$ & $\begin{array}{c}\text { Time } \\
\text { Commitment }^{2}\end{array}$ & $\begin{array}{l}\text { Complaints } \\
\text { per Permit }^{3}\end{array}$ \\
\hline Kelowna & & & & & & $\mathbf{0}$ & None & $\begin{array}{l}\text { High according to } \\
\text { newspapers }\end{array}$ \\
\hline Nanaimo & & & & & & $\mathbf{0}$ & None & $\begin{array}{l}\text { High according to } \\
\text { newspapers }\end{array}$ \\
\hline Highlands & yes & $\begin{array}{l}\text { within } \\
100 \mathrm{~m}\end{array}$ & no limit & & & 4 & $\begin{array}{c}\sim 0.5-1 \\
\mathrm{hr} / \text { permit } \\
1-2 \mathrm{hr} / \mathrm{mo}\end{array}$ & $\begin{array}{c}\sim 12 \text { to } 24 \text { complaints } / y r \\
1 \text { call } / \text { permit }\end{array}$ \\
\hline Colwood & yes & $\begin{array}{l}\text { within } \\
300 \mathrm{~m}\end{array}$ & no limit & $\begin{array}{l}\text { within } \\
60 \mathrm{~m}\end{array}$ & & 3 & $\begin{array}{c}\sim 1 \mathrm{hr} / \text { permit } \\
1-2 \mathrm{hr} / \mathrm{mo}\end{array}$ & $\begin{array}{l}\sim 4 \text { complaints } / y r \\
1 \text { call } / 3 \text { to } 6 \text { permits }\end{array}$ \\
\hline Sechelt & yes & $\begin{array}{c}\text { as per } \\
\text { specialist }\end{array}$ & $50 \mathrm{~mm} / \mathrm{s}$ & $\begin{array}{l}\text { within } \\
150 \mathrm{~m}\end{array}$ & specialist & 2 & $\begin{array}{c}\sim 16 \mathrm{hr} / \text { permit } \\
1 \mathrm{hr} / \mathrm{wk}\end{array}$ & $\begin{array}{c}<1 \text { complaint } / \mathrm{yr} \\
<1 \text { call } / 3 \text { to } 4 \text { permits }\end{array}$ \\
\hline $\begin{array}{c}\text { West } \\
\text { Vancouver }\end{array}$ & yes & as per P.Eng. & $50 \mathrm{~mm} / \mathrm{s}$ & $\begin{array}{l}\text { as per } \\
\text { P.Eng. }\end{array}$ & P.Eng. & 1 & $\begin{array}{c}\sim 1.5 \mathrm{hr} / \mathrm{permit} \\
2-3 \mathrm{hr} / \mathrm{wk}\end{array}$ & $\begin{array}{c}<1 \text { complaint } / \mathrm{yr} \\
<1 \text { call } / 30 \text { to } 40 \text { permits }\end{array}$ \\
\hline
\end{tabular}

${ }^{1}$ Subjective risk assessment (via authors' opinion informed by discussion with personnel working at each municipality) of the chance that a municipality will be sued if there were an incident $(0=$ lowest, 4 = highest $)$

${ }^{2}$ Time spent on administration/enforcement of bylaw by the municipal engineers/inspectors

${ }^{3}$ Phone calls/claims/inquiries made to municipality

The key aspects in the recommended bylaw are that:

1. A permit must be issued by the municipality for all blasting.

2. Nearby residents must be informed of the blasting activities and provided with information about what to expect in terms of noise and vibrations and the timing of the blasts.

3. A pre-blast survey shall be completed on structures within a specified distance of the blast area.

4. Blasts must occur during prescribed daylight hours.

5. Vibration limits in terms of peak particle velocities and air overpressures measured at nearby structures are required to be below specified limits.

Municipalities should modify or develop their own "Other Rights and Remedies," section in the bylaw and have a lawyer/solicitor that specializes in municipal law review the entire bylaw.

The requirements for a pre-blast survey combined with vibration monitoring during the blast are important elements of the bylaw because most disputes arising from urban blasts are associated with claims for damage believed by residents to have resulted from the blasting vibrations. A blasting contractor needs evidence to prove that damage claims did not arise from the blasting.

\section{Conclusions and Recommendations}

Media reports of blasting in urban areas in Canada continue to document residents that are angry and upset with blasting practices in their neighborhoods. A survey found that most municipalities in British Columbia do not have municipal blasting bylaws. While provincial regulations do exist to protect persons and property, they typically do not prescribe the need for notification of planned blasts, pre-blast surveys, and blasting monitoring. The lack of these explicit requirements in provincial regulations potentially creates conflict between blasting companies and nearby affected residents.

After consultation with municipal engineers, inspectors, blasting contractors and consultants, a generic urban blasting bylaw was developed. It is recommended that municipalities consider adoption of the bylaw. Furthermore, it is recommended that the Union of B.C. Municipalities and the Municipal Insurance Association of B.C. consider promotion of a single harmonized blasting bylaw for all municipalities across the province. Alternatively, provinces could modify their existing blasting regulations to include explicit requirements to 1) notify nearby homeowners of planned blasts, 2) conduct pre-blast surveys, and 3) measure ground vibrations and air pressures. Clearly, even without legislated requirements, it is best practices for a blasting company to perform these activities when blasting in urban environments to reduce their exposure to complaints and frivolous claims for property damage.

\section{Appendix - Generic Blasting By law}

[Interested] Regional Municipality

Bylaw Number [00000] Respecting Blasting

\section{General}

\section{Number and Short Title}

1. This Bylaw shall be known as Bylaw Number [00000] and shall be cited as the "Blasting Bylaw." 
Jurisdiction

2. The Blasting Bylaw contains laws that must be complied with, in addition to those blasting laws that are regulated by the provincial and federal governments.

Definitions

3. In this Blasting Bylaw:

a) "Affected Community" means all properties within a distance of $150 \mathrm{~m}$ from the Blasting Area, unless adjusted by the Consultant.

b) "Air Overpressure" means the airborne disturbance which results from Blasting, which may or may not be audible, measured in linear decibels (dBL).

c) “Applicant" means a person who has applied for a Blasting Permit under this Bylaw.

d) "Blaster" means a person named on a valid Urban Blasting Certificate issued by the Province of British Columbia.

e) "Blasting" means the handling, preparation and use of explosives, but does not include delivery or storage by a properly qualified person in accordance with Federal and Provincial Law.

f) "Blasting Area" means the zone extending $15 \mathrm{~m}$ of all directions from the place in which holes will be loaded with explosives to be detonated.

g) “Consultant” means a Professional Engineer, or a person with other relevant qualifications or reputation acceptable to the Inspector, that has expertise in blasting in urban areas with at least 5 years blast consulting experience, and is independent of the Blaster and the explosives manufacturer or distributor.

h) "Inspector" means the person appointed by the Chief Administrative Officer of the Municipality to be the Inspector of Blasting or their designate.

i) “Municipality" means the [Interested] Regional Municipality.

j) "Particle Velocity" means the measure of the intensity of ground vibration, measured in millimeters per second.

k) “Qualified Monitor" means a person who is the Consultant, or a person working under the supervision of a Consultant, trained on the proper use of the monitoring instruments by a representative of the manufacturer or distributor of the monitoring instruments or other competent individual, and shall not be the Blaster or the Applicant, or an employee of the Blaster or the Applicant.

\section{Blasting Permit}

4. (1) No person shall carry out or cause to be carried out Blasting in the Municipality without a Blasting Permit first having been obtained from the Inspector.

(2) A Blasting Permit shall not be issued to an Applicant unless the Applicant is a Blaster, the Applicant has a Blaster in his/her employ, or the Applicant has a contract with a Blaster in respect of the work for which the Blasting Permit is intended.

(3) Notwithstanding subsection (1), the inspector may give permission for Blasting without a Blasting Permit in an emergency situation.

Hours of Blasting

5. (1) No person shall carry out or cause to be carried out Blasting on a Saturday, a Sunday, Remembrance Day, or a holiday as defined in the Interpretation Act, R.S.N.S. 1989, c.35, as amended from time to time.

(2) No person shall carry out or cause to be carried out Blasting outside of daylight hours.

(3) Notwithstanding to subsections (1)and (2), the council of the Municipality may allow the Inspector to issue a Blasting Permit to carry out Blasting on weekends or holidays if such operation is in the interest of public convenience. In such cases, the hours of Blasting shall be as per 5(2).

\section{Limits}

\section{Particle Velocity}

6. No person shall carry out or cause to be carried out Blasting which results in a Peak Particle Velocity measured at the closest structure to the blast which exceeds $50 \mathrm{~mm} / \mathrm{s}$, unless otherwise specified by the Consultant and accepted by the Inspector.

\section{Maximum Air Overpressure}

7. No person shall carry out or cause to be carried out Blasting which results in an Air Overpressure measured at the closest inhabited building to the blast which exceeds $120 \mathrm{~dB}(\mathrm{~L})$, measured on the linear scale, unless otherwise specified by the Consultant and accepted by the Inspector.

\section{Activities During Blasting}

\section{Pre-Blast Survey}

8. (1) No person shall carry out or cause to be carried out Blasting unless a pre-blast survey is completed on every structure within $65 \mathrm{~m}$ of the Blast Area unless adjusted by the Consultant, and which meets the following requirements.

a) Notification, containing project description / location, the blasting contractor's name, the name of the firm conducting the survey, and an approximate start and completion date for the project, is distributed to all property owners in the area to be surveyed.

b) Appointments are made and the survey is carried out in a timely manner and in advance of the commencement of Blasting on the project.

c) Each property owner is contacted in person and if the homeowner cannot be contacted, notification is left in the mailbox or door advising the owner who to contact to schedule an appointment.

d) The survey consists of high quality video photography, unless still photographs are preferred by the property owner, of the structure, in reproducible format, and which provides an overview of the entire structure, interior and exterior, provided consent is given by the property owner or his/her respective representative. 
e) The survey shows fences, sidewalks, trees, and other similar features adjoining the property.

f) The video record may be reviewed by the property owner upon request.

(2) Notwithstanding subsection (1), a pre-blast survey shall not be required before a Blasting Permit is issued in the event the property owner cannot be contacted after a minimum of four visits to the property, with a maximum of one visit per day, or refuses entry to the property.

Notification

9. (1) No person shall carry out or cause to be carried out Blasting unless a notification pamphlet is delivered by hand after the Blasting Permit is issued and at least two days (48 hours) prior to the commencement of Blasting, to every property owner or business within the Affected Community which shall contain:

a) the name of the person or company responsible for Blasting, including a contact person and telephone number,

b) the intended date and time when Blasting shall commence and its expected duration, and

c) the location of Blasting.

(2) No person shall carry out or cause to be carried out Blasting within $300 \mathrm{~m}$ of a school, hospital, or other health care facility unless:

a) such notice as required by subsection (1)has been given to the senior administrator of the school, hospital, or other health care facility, and

b) the senior administrator is also informed at least 2 hours prior to each blast.

Blaster Required

10. No person shall carry out or cause to be carried out Blasting unless the Blasting is under the care and control of a Blaster.

\section{Drilling Dust Control}

11. No person shall carry out or cause to be carried out Blasting without the use of an acceptable dust collection system as part of the drill machine.

\section{Blast Monitoring}

12. No person shall carry out or cause to be carried out Blasting unless:

a) a Qualified Monitor monitors every blast, and

b) blast monitoring equipment and procedures meet the standards of the International Society of Explosive Engineers Blasters Manual.

\section{Hole Size}

13. No person shall carry out or cause to be carried out Blasting where blast holes exceed a diameter of $70 \mathrm{~mm}$, unless adjusted by the Consultant and approved in writing by the Inspector.

Submit Records
14. (1) During the course of blasting, the Consultant shall review the blast records and confirm to the Blaster and/or Inspector, if requested, that blasting is being carried out in accordance with the specifications of this bylaw, and shall immediately report any problems, unusual circumstances or inconsistencies to the Blaster and/or Inspector.

(2) The Consultant will report, within 24 hours to the Blaster and/or Inspector, any instance when, and under what circumstances, vibrations and/or Air Overpressure exceeded the specified maximum limits. This report will include a written explanation for the excessive Air Overpressure and Particle Velocity level(s) as well as a description of corrective actions.

\section{Administration}

\section{Blasting Permit Application}

15. (1) The Applicant for a Blasting permit shall make written application on a form provided by the Inspector.

(2) The application shall contain the following information:

a) the Applicant's name, address, telephone number, and type of business,

b) a contact person's name, title, and telephone number,

c) a description of the scope of work, including purpose for which Blasting is required,

d) the date upon which work is proposed to commence and the probable duration,

e) a copy of a valid urban blasting certificate issued by the Worker's Compensation Board or the B.C. Ministry of Mines to the blaster who will undertake the work,

f) a certificate of insurance on a form acceptable to the Inspector which provides a policy of commercial general liability for bodily injury and property damage in the amount of $\$ 5,000,000$ per occurrence which includes the [Interested] Regional Municipality as an additional insured, a cross liability clause and a Blasting endorsement for the full limits of the policy, and g) such other information as the Inspector may require.

\section{Other Rights and Remedies}

Terms and Conditions, penalties, duration, fees etc. to be written by [Interested] Municipalities Done and passed in Council this [\#] day of [Month], [Year]

Mayor:

Municipal Clerk:

\section{REFERENCES}

[1] C. H. Dowding, Construction Vibrations. Prentice Hall, Upper Saddle River, NJ, 1996.

[2] ISEE Blaster's Handbook. International Society of Explosives Engineers Inc. 18 ${ }^{\text {th }}$ ed., Cleveland, OH, 2011. 
[3] D. E. Siskind, M. S. Stagg, J. W. Kopp, C. H. Dowding, Structure response and damage produced by ground vibration from surface mine blasting. RI 8507, U.S. Bureau of Mines, 1980.

[4] Deutsches Institut für Normung, DIN 4150 Deutsche Normen: Erschütterungen im Bauwesen - Einwirkungen auf bauliche Anlagen, Germany, 1986.

[5] D. E. Siskind, V. J. Stachura, M. S. Stagg, J. W. Kopp, Structure response and damage produced by airblast from surface mine blasting. RI 8485 U.S. Bureau of Mines, 1980.

[6] A. B. Richards, Prediction and control of air overpressure from blasting in Hong Kong. Geo Report No. 232, Geotech. Eng. Office, Civil Eng. and Dev. Dep., The Gov. of the Hong Kong Special Admin. Region, 2008.

[7] T. D. Stark, Is construction blasting still abnormally dangerous? J. of Leg. Affairs and Dispute Resol. in Eng. and Constr. 2(4), 208-217, 2010.

[8] Atlas Powder Company, Explosives and Rock Blasting, Atlas Powder Company, Dallas, TX, 1987.

[9] M. R. Svinkin, Minimizing construction vibration effects. Prac. Period. on Struct. Des. and Constr. 9(2), 108-115, 2004.

[10] L. L. Oriard, Explosive Engineering, Construction Vibrations and Geotechnology. International Society of Explosives Engineers, Cleveland, OH, 2005

[11] G. F. Revey, Managing rock blasting work in urban environments. Prac. Period. on Struct. Design and Const. 11(2): 86-92, 2006.

[12] A. Nieoczym, Council imposes new blasting requirements. Online available from

http://www.kelowna.com/2010/01/12/council-imposes-newblasting-requirements. 2010.

[13] M. Whitehouse, City moving to regulate blasting. The Sudbury Star. Online available fromhttp://www.thesudburystar.com/2010/04/22/city-movin g-to-regulate-blasting, 2010.

[14] J. Gerresten, RE: residential/commercial blasting complaints - City of Greater Sudbury. City of Sudbury Agendas: Appendix C - Minist. of the Environ. Lett. Online available fromwww.greatersudbury.ca/agendas/index.cfm?pg=feed\&a ction $=$ file \&attachment $=3863$.pdf.

[15] City of Kelowna, Council imposes new blasting requirements, http://www.kelowna.com/2010/01/12/council-imposes-newblasting-requirements/, 2010.

[16] R. Leclair, Report to Transportation and Transit Committee and Council, Ref No: ACS2003-TUP-INF-0016. Online available from

http://www.ottawa.ca/calendar/ottawa/citycouncil/ttc/2003/0 9-17/ACS2003-TUP-INF-0016.htm, 2003.

[17] T. Gorman, City edges closer to blasting regulations, Nanaimo News Bulletin, May $6^{\text {th }} 2010$, Black Press, 2010.

[18] M. Whitehouse, The price of progress: blasting shakes up south end. The Sudbury Star. Online available from http://www.thesudburystar.com/2010/04/24/accent-the-price -of-progress-blasting-shakes-up-south-end, 2010.

[19] District of West Kelowna, Good Neighbour Bylaw No. 0071.02 Online available from http://www.districtofwestkelowna.ca/Modules/ShowDocu ment. aspx ?documentid $=729$.

[20] W. Moore, TNT not a blast for DWK resident. West Kelowna News. Online available from http://www.castanet.net/news/West-Kelowna/59007/TNTnot-a-blast-for-DWK-resident, 2010.

[21] J. Loeb, Regulatory mitigation of the adverse environmental effects of urban blasting. M.A.Sc. thesis, University of British Columbia, Kelowna, B.C., 2012. Online available from http://hdl.handle.net/2429/42948 .

[22] District of West Vancouver, Blasting Bylaw No. 4024. Online available from

http://westvancouver.ca/uploadedFiles/Your_Government/B ylaws/BlastingBylawNo.4024,1996.pdf.

[23] District of Sechelt, Blasting Bylaw No. 458. Online available fromhttp://www.district.sechelt.bc.ca/Portals/0/Public\%20D ocument\%20Library/Bylaws/458,\%202007\%20-\%20Blastin g\%20Regulation.pdf.

[24] City of Colwood, Blasting Bylaw No. 272. Online available fromhttp://colwood.fileprosite.com/content/pdfstorage/E3D4 01B2D5CC45269B0E38499ED595F0-CONSOLIDATION $\% 20-\% 20$ Blasting\%20Bylaw\%20No-\%20272.pdf.

[25] District of Highlands, A Bylaw to Regulate Blasting within the District of Highlands, Bylaw No. 67. Online available from

http://highlands.bc.ca/bylaws/051-075/67-Blasting\%20Byla w.pdf.

[26] Halifax Regional Municipality, Bylaw Number B-600 Respecting Blasting. Online available from http://www.halifax.ca/legislation/bylaws/hrm/documents/B y-lawB-600.pdf.

[27] A. Stelmakowich, The buffer zone. Canada's Occupational Health and Saf. Mag. Online available from http://www.ohscanada.com/news/the-buffer-zone/10001994 34/, 2005. 